\title{
Efficacy of ACC
}

(1-aminocyclopropane-1-carboxylic acid) as a Chemical Thinner Alone or Combined with Mechanical Thinning for Japanese Plums (Prunus salacina)

\author{
Karen Inge Theron ${ }^{1}$ \\ Department of Horticultural Science, Stellenbosch University, \\ Private Bag X1, Matieland 7602, South Africa \\ Human Steenkamp \\ Stellenbosch University, Stellenbosch 7599, South Africa \\ Willem Jacobus Steyn \\ Department of Horticultural Science, University of Stellenbosch, \\ Victoria Street, Stellenbosch 7600, South Africa \\ Additional index words. 6-benzyladenine (6-BA), thinning, yield, fruit quality
}

\begin{abstract}
Thinning is a labor-intensive and expensive, but important practice in japanese plum production requiring new thinning strategies. The purpose of this study was to evaluate a new chemical thinner 1-aminocyclopropane-1-carboxylic acid (ACC) on 'Laetitia', 'Fortune', and 'African Rose ${ }^{\mathrm{TM}}$ '. ACC was also combined with 6benzyl adenine (6-BA) and in one season on 'African Rose ${ }^{\mathrm{TM}}$, with mechanical thinning using the Darwin $300^{\mathrm{TM}}$ or hand thinning during bloom. All the foliar applications were made when the average fruitlet diameter was $7-10 \mathrm{~mm}$ using a spray volume of $1000 \mathrm{~L} \cdot \mathrm{ha}^{-1}$ under slow drying conditions. Significant thinning effects were found in all the trials conducted over the two seasons. ACC consistently reduced the hand-thinning requirement at commercial hand thinning in both seasons in 'African Rose ${ }^{\mathrm{TM}}$ '. In the second season there was a linear decrease in yield and an increase in fruit size as the $\mathrm{ACC}$ rate increased from the low to medium rate before flattening off. The combination treatment of ACC and the Darwin $300^{\mathrm{TM}}$ used in the 'African Rose ${ }^{\mathrm{TM}}$, trial thinned more aggressively, improved fruit size and shifted harvest earlier. The yield however was not lower than that of the control treatment. 6BA was included in all trials to prevent ACC-induced leaf drop, and generally did not thin fruitlets, except in the case of 'Laetitia' where the combination with ACC resulted in stronger thinning. Cultivars differed in their sensitivity to ACC and the rate for each cultivar should be determined separately. The recommended ACC rate for 'African Rose ${ }^{\mathrm{TM}}$, would be $600 \mu \mathrm{L} \cdot \mathrm{L}^{-1}$ and for 'Laetitia' $400 \mu \mathrm{L} \cdot \mathrm{L}^{-1}$. For 'Fortune' a rate recommendation is not possible at this stage, thus further trials should be conducted. No broken stones were observed in fruit in any trial. Also, no leaf drop/phytotoxicity was recorded in any trial when ACC was applied during cool, slow-drying conditions.
\end{abstract}

Annual cropping of fruit trees is very important and to achieve this, flower or fruit thinning is practiced. By reducing the number of fruit on the tree, the remaining fruit will develop to the optimal size of higher quality and return bloom the next season will be adequate for a good crop load (Njoroge and Reighard, 2008). Thinning can be done at various times, i.e., prebloom, full bloom, and postbloom, and the cheapest and earliest method of thinning is pruning (Njoroge and Reighard, 2008). However, even when stone fruit trees are properly

Received for publication 7 Oct. 2016. Accepted for publication 16 Nov. 2016

1Corresponding author. E-mail: kit@sun.ac.za. pruned, they still often set too many fruit (DeJong and Grossman, 1994). The severity of thinning as well as the timing is closely linked to the reproductive and vegetative performance of the tree (Costa and Vizzotto, 2000). Appropriate thinning must therefore be done annually, to achieve the advantages it has on flower number, fruit size, fruit quality, fruit-to-shoot ratio, and in preventing alternate bearing (Costa et al., 1983; Seehuber et al., 2011).

Chemical thinning plums would reduce hand thinning substantially, but currently, chemical thinners available for stone fruit thinning are limited (Seehuber et al., 2011). One chemical thinning approach for plums is to use gibberellins, e.g., gibberellic acid $\left(\mathrm{GA}_{3}\right)$, but results are often inconsistent.
$\mathrm{GA}_{3}$ applied during flower induction will reduce flowering the next season and indirectly reduce the number of fruit, which will lead to a reduction in hand-thinning costs (González-Rossia et al., 2006). Therefore, to be effective, $\mathrm{GA}_{3}$ must be applied when flower-bud differentiation can be affected (Costa and Vizzotto, 2000). The main reason why $\mathrm{GA}_{3}$ sprays are not used as a chemical thinner is "thinning" is performed long before bloom and climatic conditions, i.e., frost during bloom, might still negatively influence fruit set of the fewer blossoms (Byers et al., 1990; Costa and Vizzotto, 2000).

A preferred alternative approach is using blossom thinners that burn flower parts and prevent fertilization and therefore fruit set (Southwick et al., 1996). The surfactant, Tergitol-TMN-6, significantly reduced fruit set and increased fruit size in 'Empress' plums at various rates $\left(7.5\right.$ and $\left.12.5 \mathrm{~mL} \cdot \mathrm{L}^{-1}\right)$ (Fallahi et al., 2006). Tergitol-TMN-6 is effective over a wide range of phenological stages from full bloom to petal fall, which allows for a longer window of application (Wilkins et al., 2004). The current recommendation for stone fruit is to apply Tergitol-TMN-6 at $75 \%$ to $80 \%$ full bloom at $7.5-12.5 \mathrm{~mL} \cdot \mathrm{L}^{-1}$ (Fallahi et al., 2006), but in South Africa, blossom thinners have not been very successful.

A number of chemical thinners are used commercially on pome fruit, e.g., ethephon, 6-benzyladenine (6-BA) and naphthalene acetic acid (NAA) (Byers and Carbaugh, 1991). Ethephon releases ethylene which stimulates fruit abscission (Wertheim, 2000). Ethephon at $250 \mu \mathrm{L} \cdot \mathrm{L}^{-1}$ applied to 'Victoria' plums at full bloom did not reduce fruit set, whereas $75 \mu \mathrm{L} \cdot \mathrm{L}^{-1}$ Ethephon combined with $10 \mu \mathrm{L} \cdot \mathrm{L}^{-1} \mathrm{NAA}$ applied $27 \mathrm{~d}$ after full bloom did reduce fruit set significantly. Both treatments advanced fruit maturity (Meland, 2007). The return bloom the next season, however, was not improved by either treatment (Meland and Birken, 2010). A new chemical thinner currently being evaluated in pome fruit is ACC (Schupp et al., 2012), but its efficacy on japanese plums is unknown. According to Adams and Yang (1979), ACC is effectively converted to ethylene in apple tissue. Further studies on mung beans confirmed that ACC, a precursor of ethylene, increased the corresponding rate of ethylene production (Yoshii and Imaseki, 1981).

Mechanical thinning is a relatively new development in the stone fruit industry and can be used to remove both flowers and fruitlets (Miller et al., 2011; Theron et al., 2015). Hand thinning could be reduced by mechanical thinning by $28 \%$. In addition, the effect of mechanical thinning is immediate and not influenced by climatic conditions (Martín et al., 2010). Inconsistent results, however, have hampered the successful implementation of mechanical thinning in stone fruit (Reighard and Byers, 2009). Miller et al. (2011), Baugher et al. (2009, 2010) and Schupp et al. (2008) found added 
economic benefits in producing larger peach fruit while reducing follow-up hand thinning when they combined mechanical bloom thinning with green-fruit hand thinning (Miller et al., 2011; Baugher et al., 2009; Baugher et al., 2010; Schupp et al., 2008). The Darwin ${ }^{\mathrm{TM}}$ does not thin selectively enough and will therefore not replace hand thinning completely (Miller et al., 2011). More recently De Villiers (2014) evaluated the Darwin $300^{\mathrm{TM}}$ on japanese plums and was able to significantly reduce the time it took to hand thin trees. In two of the three trials on the plums 'African Rose ${ }^{\mathrm{TM}}$ ', [cv. ARC PR-4 (PR00-01)] and 'Laetitia', it also resulted in an increase in fruit size (De Villiers, 2014), but the tree training system has to be adapted to the machine.

The purpose of this study was to evaluate the efficacy of chemical thinners, i.e., ACC and 6-BA applied at the fruitlet stage to various japanese plum cultivars on fruit set, yield, and fruit quality. ACC is a precursor of ethylene and increases ethylene production (Adams and Yang, 1979), which can lead to leaf drop, therefore 6-BA was included in this study to try and prevent phytotoxicity/ leaf drop possibly induced by the ACC (Zieslin and Gottesman, 1983). The chemical thinning treatments were also combined with mechanical thinning using the Darwin $300^{\mathrm{TM}}$ or hand thinning during bloom on 'African Rose ${ }^{\mathrm{TM}}$ '.

\section{Materials and Methods}

Plant material and site description for the $2013 / 2014$ season. In the 2013/2014 season, a trial was conducted on the japanese plum cultivar African Rose ${ }^{\mathrm{TM}}$ on the farm Sandrivier $\left(33^{\circ} 35^{\prime} 58.0^{\prime \prime} \mathrm{S}, 18^{\circ} 55^{\prime} 40.1^{\prime \prime}\right.$ E) near Wellington in the Western Cape, South Africa. The mature, uniform flowering 'African Rose $^{\mathrm{TM}}$ ' trees, on Mariana rootstock, were planted in 2009 at a spacing of $3.5 \mathrm{~m} \times$ $1 \mathrm{~m}$. The planting system used for this orchard is a V-system and trees are trained to a 9-wire hedge with $10 \%$ 'Pioneer' trees as the cross pollinator.

Experimental layout for the 2013/2014 season. Two products were evaluated, viz., ACC (Valent BioSciences Corporation, Libertyville, IL) and 6-BA (MaxCel ${ }^{\circledR}$; Valent BioSciences Corporation). Seven treatments were used in a randomized complete block design with eight single tree replications. The treatments were as follows: 1) an untreated control, 2) 6-BA $\left.\left(100 \mu \mathrm{L} \cdot \mathrm{L}^{-1}\right), 3\right)$ 6-BA $\left.\left.\left(300 \mu \mathrm{L} \cdot \mathrm{L}^{-1}\right), 4\right) \mathrm{ACC}\left(150 \mu \mathrm{L} \cdot \mathrm{L}^{-1}\right), 5\right) \mathrm{ACC}$ $\left.\left(300 \mu \mathrm{L} \cdot \mathrm{L}^{-1}\right), 6\right)$ ACC $\left(500 \mu \mathrm{L} \cdot \mathrm{L}^{-1}\right)$, and 7) 6-BA $\left(100 \mu \mathrm{L} \cdot \mathrm{L}^{-1}\right)$ plus ACC $\left(500 \mu \mathrm{L} \cdot \mathrm{L}^{-1}\right)$ as a tank mix. All applications were made on 11 Sept. 2013 at a fruitlet diameter of 7-10 mm. Hand thinning was done on 1 Oct. 2013 and trees were harvested on 18 Nov. 2013.

Plant and site description for the 2014/ 2015 season. Trials were conducted on the japanese plum cultivars African Rose ${ }^{\mathrm{TM}}$, Fortune, and Laetitia. Mature, uniformflowering 'Fortune' and 'African Rose ${ }^{\mathrm{TM}}$ ' trees on the farm Sandrivier $\left(33^{\circ} 35^{\prime} 58.0^{\prime \prime} \mathrm{S}\right.$, $18^{\circ} 55^{\prime} 40.1^{\prime \prime}$ E) near Wellington in the Western Cape, South Africa, were used. A uniformflowering 'Laetitia' orchard on Fransmanskraal (333' $34.7^{\prime \prime}$ S, $\left.18^{\circ} 49^{\prime} 06.4^{\prime \prime} \mathrm{E}\right)$, Devon Valley, near Stellenbosch was selected. The trial on 'African Rose ${ }^{\mathrm{TM}}$ ' was in the same orchard as in the previous season, but on different trees. The 'Fortune' on Mariana rootstocks were planted in 2005 at $4.5 \mathrm{~m} \times$ $0.75 \mathrm{~m}$ and trained to a V-hedge system. The cross pollinator in this orchard was $10 \%$ 'Angeleno'. The 'Laetitia' trees on Mariana rootstocks were relatively young, planted in 2011 at a spacing of $3.25 \mathrm{~m} \times 1.5 \mathrm{~m}$ and trained to a palmette system. The cross pollinator was 'Sunbreeze' and planted every alternate row.

Experimental layout for the 2014/2015 season. The 'African Rose ${ }^{\mathrm{TM}}$ ' trial consisted of 10 treatments in a randomized complete block design with 10 replicates The treatments were as follows: 1) an untreated control, 2) Darwin $300^{\mathrm{TM}}$ at full bloom (12 Aug. 2014), 3) hand flower thinning, where every second flower cluster was removed at full bloom, 4) 6-BA $\left.\left(100 \mu \mathrm{L} \cdot \mathrm{L}^{-1}\right), 5\right) \mathrm{ACC}$ $\left.\left.\left(400 \mu \mathrm{L} \cdot \mathrm{L}^{-1}\right), 6\right) \mathrm{ACC}\left(600 \mu \mathrm{L} \cdot \mathrm{L}^{-1}\right), 7\right) \mathrm{ACC}$ $\left(800 \mu \mathrm{L} \cdot \mathrm{L}^{-1}\right)$, 8) 6-BA $\left(100 \mu \mathrm{L} \cdot \mathrm{L}^{-1}\right)$ plus ACC $\left(800 \mu \mathrm{L} \cdot \mathrm{L}^{-1}\right)$ as a tank-mix, 9) Darwin $300^{\mathrm{TM}}$ at full bloom plus ACC $\left(600 \mu \mathrm{L} \cdot \mathrm{L}^{-1}\right)$, and 10) Darwin $300^{\mathrm{TM}}$ at full bloom plus ACC $\left(800 \mu \mathrm{L} \cdot \mathrm{L}^{-1}\right)$. For the mechanical thinning treatments, each replicate consisted of five trees with the middle tree used to record data. The tractor speed was $4.8 \mathrm{~km} \cdot \mathrm{h}^{-1}$ and rotor speed $160 \mathrm{rpm}$. All chemical applications were made on 3 Sept. 2014 at a fruitlet diameter of $8-10 \mathrm{~mm}$. Hand thinning was done on 16 Sept. 2014 and trees were harvested on 10, 14, and 17 Nov. 2014. The 'Fortune' and 'Laetitia' trials each consisted of six treatments in a randomized complete block design with 10 replicates as follows: 1) an untreated control, 2) 6-BA $\left(100 \mu \mathrm{L} \cdot \mathrm{L}^{-1}\right)$, 3) ACC $\left(200 \mu \mathrm{L} \cdot \mathrm{L}^{-1}\right)$, 4) ACC $\left.\left(400 \mu \mathrm{L} \cdot \mathrm{L}^{-1}\right), 5\right)$ ACC $\left(600 \mu \mathrm{L} \cdot \mathrm{L}^{-1}\right)$, and 6) 6-BA $\left(100 \mu \mathrm{L} \cdot \mathrm{L}^{-1}\right)$ plus ACC $\left(600 \mu \mathrm{L} \cdot \mathrm{L}^{-1}\right)$ as a tank mix. All chemical applications were made on 1 Oct. 2014 for 'Fortune' and on 3 Oct. 2014 for 'Laetitia' at a fruitlet diameter of $8-10 \mathrm{~mm}$. Hand thinning was done on 15 and 17 Oct. 2014 and trees were harvested on 22 and 26 Dec. 2014 and 14 Jan. 2015 for 'Fortune' and 'Laetitia', respectively.

Treatment application. All the foliar applications were made using a motorized knapsack sprayer (STIHL, Pietermaritzburg, South Africa) when the average fruitlet size was $7-10 \mathrm{~mm}$ at a rate of $1000 \mathrm{~L} \cdot \mathrm{ha}^{-1}$ under slow drying conditions when the temperature was between 10 and $15^{\circ} \mathrm{C}$. At least one tree was left between the treated trees and a buffer row, where more than one row was needed for the trial, to prevent drift effects. The conditions following the applications were favorable for at least $5 \mathrm{~d}$ with temperatures above $18^{\circ} \mathrm{C}$.

Data collection. In all trials, the same data were recorded. After the application of the treatments, a period of at least 2 weeks was allowed for fruitlets to drop. Hand thinning was done according to standard commercial practices during which the largest fruitlets were retained, remaining fruitlets spaced and thinned to the required number per tree. All fruitlets thinned by hand were collected and brought back to the laboratory, weighed and counted. At each commercial harvest date, the yield per tree was recorded. A sample of 30 fruit per harvest was brought to the laboratory for further evaluation. The following was recorded on each fruit: fruit weight, diameter, length, firmness, and the incidence of broken stones. Fruit firmness was determined using the GÜSS texture analyzer with a 11-mm tip (Guss electronic model GS 20; Strand, South Africa), while broken stones were recorded as either present or not. Return bloom was not recorded as all trees flowered profusely the following spring and no visual differences were seen.

Statistical analysis. The data were analyzed using SAS Enterprise guide 5.1 (SAS Institute Inc., Cary, NC) using the linear model procedure and the pairwise $t$ test to determine the least significant difference when the F-statistic indicated significance at $P<0.05$. Single $\mathrm{df}$, and orthogonal and polynomial contrasts were fitted where applicable.

\section{Results}

Results for the 2013/2014 season: 'African Rose $^{\mathrm{TM}}$ '. The highest rate of ACC $\left(500 \mu \mathrm{L} \cdot \mathrm{L}^{-1}\right)$ significantly reduced the number of fruitlets that had to be thinned by hand during commercial hand thinning compared with the control (Table 1). The increase in ACC rate resulted in a linear decrease in the number of fruitlets that needed hand thinning. 6-BA did not thin significantly, not even at the high rate. The addition of 6-BA to the high rate of ACC did not affect the thinning efficacy (Table 1) and no leaf drop/phytotoxicity was observed in this trial. No significant differences were found in total yield per tree (Table 1) or yield at either of the two harvest dates or harvest distribution (data not shown). There was no significant difference in the average fruit weight from a combined fruit sample from the two harvest dates (Table 1).

Results from the 2014/2015 season: 'African Rose ${ }^{\mathrm{TM}}$ '. Both the Darwin $300^{\mathrm{TM}}$ and the hand flower thinning treatment at full bloom as well as all ACC applications significantly reduced the number of fruitlets that had to be thinned by hand during commercial hand thinning compared with the control (Table 2). With increasing ACC rate, a linear decrease in the number of fruitlets that needed hand thinning was found. The combination of the ACC and Darwin $300^{\mathrm{TM}}$ significantly reduced the number of fruitlets that had to be thinned compared with the ACC treatments on their own $(P=0028)$ (Table 2). 6-BA did not result in significant thinning and the addition of 6-BA to the high rate of ACC did not affect the thinning efficacy (Table 2). No leaf drop/phytotoxicity was observed in this trial. All the treatments, except 6-BA, significantly increased the 
Table 1. Effect of 6-benzyladenine (6-BA) and 1-aminocyclopropane carboxylic acid (ACC) on handthinning requirement, yield per tree, and average fruit weight at harvest in 'African Rose ${ }^{\mathrm{TM}}$ ' $\mathrm{plum}^{\text {at }}$ Sandrivier, Wellington District, South Africa (2013/2014).

\begin{tabular}{lccc}
\hline Treatment & $\begin{array}{c}\text { Avg number of } \\
\text { fruitlets thinned by hand }\end{array}$ & $\begin{array}{c}\text { Total yield } \\
\text { per tree }(\mathrm{kg})\end{array}$ & $\begin{array}{c}\text { Avg fruit wt (g) over } \\
\text { two harvests }\end{array}$ \\
\hline Control & $1,799 \mathrm{a}$ & $13.7^{\mathrm{NS}}$ & $54.1^{\mathrm{NS}}$ \\
6-BA $100 \mu \mathrm{L} \cdot \mathrm{L}^{-1}$ & $1,868 \mathrm{a}$ & 12.9 & 54.7 \\
6-BA $300 \mu \mathrm{L} \cdot \mathrm{L}^{-1}$ & $1,747 \mathrm{ab}$ & 13.3 & 52.8 \\
ACC $150 \mu \mathrm{L} \cdot \mathrm{L}^{-1}$ & $1,852 \mathrm{a}$ & 14.0 & 56.7 \\
ACC $300 \mu \mathrm{L} \cdot \mathrm{L}^{-1}$ & $1,572 \mathrm{abc}$ & 13.9 & 56.0 \\
ACC $500 \mu \mathrm{L} \cdot \mathrm{L}^{-1}$ & $1,424 \mathrm{c}$ & 13.1 & 55.8 \\
6-BA + ACCz & $1,490 \mathrm{bc}$ & 12.1 & 52.3 \\
Significance level & 0.0177 & 0.7402 & 0.1720 \\
Least significant difference 5\% & 302 & - & - \\
BA vs. ACC & 0.0537 & 0.5059 & 0.0517 \\
ACC linear & 0.0075 & 0.4191 & 0.6463 \\
ACC quadratic & 0.4596 & 0.8092 & 0.8155 \\
Control vs. rest & 0.2281 & 0.6285 & 0.6347 \\
\hline
\end{tabular}

${ }^{\mathrm{z}} 6-\mathrm{BA}\left(100 \mu \mathrm{L} \cdot \mathrm{L}^{-1}\right)+\mathrm{ACC}\left(500 \mu \mathrm{L} \cdot \mathrm{L}^{-1}\right)$.

Table 2. Effect of 6-benzyladenine (6-BA), 1-aminocyclopropane carboxylic acid (ACC), and Darwin $300^{\mathrm{TM}}$ on hand-thinning requirement, fruitlet weight at hand thinning, and yield per tree in 'African Rose $^{T M}$ ' plum at Sandrivier, Wellington District, South Africa (2014/2015).

\begin{tabular}{lccc}
\hline Treatment & $\begin{array}{c}\text { Avg number of fruitlets } \\
\text { thinned by hand }\end{array}$ & $\begin{array}{c}\text { Avg wt of hand } \\
\text { thinned fruitlets }(\mathrm{g})\end{array}$ & $\begin{array}{c}\text { Total yield } \\
\text { per tree }(\mathrm{kg})\end{array}$ \\
\hline Control & $2,597 \mathrm{a}$ & $1.4 \mathrm{e}$ & $9.9 \mathrm{abc}$ \\
Darwin at full bloom & $1,359 \mathrm{c}$ & $1.8 \mathrm{c}$ & $8.6 \mathrm{~cd}$ \\
Flower thinning & $1,890 \mathrm{~b}$ & $1.7 \mathrm{~cd}$ & $11.1 \mathrm{a}$ \\
6-BA $100 \mu \mathrm{L} \cdot \mathrm{L}^{-1}$ & $2,844 \mathrm{a}$ & $1.5 \mathrm{de}$ & $11.4 \mathrm{a}$ \\
ACC $400 \mu \mathrm{L} \cdot \mathrm{L}^{-1}$ & $1,371 \mathrm{c}$ & $1.8 \mathrm{c}$ & $10.6 \mathrm{ab}$ \\
ACC $600 \mu \mathrm{L} \cdot \mathrm{L}^{-1}$ & $1,088 \mathrm{~cd}$ & $1.9 \mathrm{c}$ & $11.2 \mathrm{a}$ \\
ACC $800 \mu \mathrm{L} \cdot \mathrm{L}^{-1}$ & $802 \mathrm{de}$ & $1.8 \mathrm{c}$ & $8.0 \mathrm{~d}$ \\
6-BA + ACC & $835 \mathrm{de}$ & $2.0 \mathrm{bc}$ & $10.0 \mathrm{abc}$ \\
Darwin + ACC $600 \mu \mathrm{L} \cdot \mathrm{L}^{-1}$ & $650 \mathrm{e}$ & $2.3 \mathrm{a}$ & $8.9 \mathrm{bcd}$ \\
Darwin + ACC $800 \mu \mathrm{L} \cdot \mathrm{L}^{-1}$ & $527 \mathrm{e}$ & $2.1 \mathrm{ab}$ & $7.9 \mathrm{~d}$ \\
Significance level & $<0.0001$ & $<0.0001$ & 0.0002 \\
Least significant difference 5\% & 325.88 & 0.29 & 1.85 \\
ACC vs. ACC + Darwin & 0.0028 & 0.0002 & 0.0691 \\
ACC linear & 0.0008 & 0.7373 & 0.0070 \\
ACC quadratic & 0.9896 & 0.7770 & 0.0178 \\
Control vs. rest & $<0.0001$ & $<0.0001$ & 0.8664 \\
\hline z6 6 B $\left(100 \mu \mathrm{L} \cdot \mathrm{L}^{-1}\right)+\mathrm{ACC}\left(800 \mu \mathrm{L} \cdot \mathrm{L}^{-1}\right)$ & & &
\end{tabular}

${ }^{\mathrm{z}} 6-\mathrm{BA}\left(100 \mu \mathrm{L} \cdot \mathrm{L}^{-1}\right)+\mathrm{ACC}\left(800 \mu \mathrm{L} \cdot \mathrm{L}^{-1}\right)$.

average weight of the thinned fruitlets significantly compared with the control (Table 2). The average weight of the thinned fruitlets for the ACC and Darwin $300^{\mathrm{TM}}$ combination treatments was significantly higher than that of the same ACC rates on their own.

Only the highest rate of ACC $\left(800 \mu \mathrm{L} \cdot \mathrm{L}^{-1}\right)$ on its own and in combination with the Darwin $300^{\mathrm{TM}}$ reduced the total yield per tree compared with the control (Table 2). There was a quadratic trend in total yield per tree with increasing ACC rate with only the highest rate reducing yield significantly. On average, all treatments altered the harvest distribution compared with the control (Table 3). The percentage of fruit that was harvested during the first harvest for the ACC and the Darwin $300^{\mathrm{TM}}$ combination treatments was significantly higher than that of the control. Almost the opposite could be observed during the third harvest, where the percentage fruit harvested for the untreated control was the highest, but not significantly higher than 6-BA treatment, ACC $400 \mu \mathrm{L} \cdot \mathrm{L}^{-1}$, and ACC $600 \mu \mathrm{L} \cdot \mathrm{L}^{-1}$ (Table 3). All the treatments increased the average fruit weight except for 6-BA and again the average fruit weight increased quadratically with the ACC rate until $600 \mu \mathrm{L} \cdot \mathrm{L}^{-1}$, and ACC $600 \mu \mathrm{L} \cdot \mathrm{L}^{-1}$ being the highest fruit weight of the ACC treatments (Table 3). Also, the average weight of the two higher ACC rates (600 and $800 \mu \mathrm{L} \cdot \mathrm{L}^{-1}$ ) and two ACC and Darwin $300^{\mathrm{TM}}$ combination treatments had significantly larger fruit compared with the rest of the treatments. The average fruit weight at the first harvest increased from the lower to the two higher rates of ACC and the average fruit weight of the ACC treatments at the first harvest was significantly higher than that of the control (data not shown). Broken stone levels were very low, ranging from $0 \%$ to $0.12 \%$ (data not shown).

'Fortune'. The two higher rates of ACC significantly reduced the number of fruitlets that had to be thinned by hand during commercial hand thinning compared with the control (Table 4). The increase in ACC rate resulted in a linear decrease in the number of fruitlets that required hand thinning. 6-BA did not result in significant thinning, but increased the hand-thinning requirement, thus increased fruit set. The addition of 6-BA to the high rate of ACC did not have an additional thinning effect. No leaf drop/phytotoxicity was observed in this trial. These treatments had no significant effect on the average weight of the handthinned fruitlets (Table 4).

The two higher ACC rates and the combination treatment with 6-BA reduced the total yield per tree significantly when compared with the control, thus resulting in a quadratic response to ACC (Table 4). The harvest distribution was not altered by any treatment, but there was a trend for advancement of harvest with increasing ACC rate $(P=0.051)$ (Table 5). The ACC $600 \mu \mathrm{L} \cdot \mathrm{L}^{-1}$ and $\mathrm{ACC}$ and 6-BA combination treatment increased the average overall fruit weight when compared with the control, whereas the 6-BA and two lower ACC rates did not have any significant effect on the average fruit weight (Table 5). No differences were found in average fruit weight at the first harvest date, whereas the two higher ACC rates and the combination treatment with 6-BA increased the average fruit weight significantly during the second harvest, and there was a linear increase in fruit weight as the ACC rates increased (data not shown). These treatments had no effect on the incidence of broken stones (data not shown).

'Laetitia'. The two higher ACC rates significantly reduced the number of fruitlets that had to be thinned by hand during commercial hand thinning compared with the control (Table 6). The increase in ACC rate resulted in a linear decrease in the handthinning requirement. 6-BA application did not result in significant thinning. The ACC and 6-BA combination treatment thinned significantly more aggressively than the ACC alone. All treatments reduced the average weight of the thinned fruitlets significantly when compared with the control (Table 6). No leaf drop/phytotoxicity was observed in this trial. The highest ACC rate and the combination treatment reduced the total yield significantly (Table 6). The two higher ACC rates and the combination treatment increased average fruit weight significantly compared with the control with a linear increase in fruit weight as the ACC application rate increased (Table 6). No broken stones were observed in any fruit.

\section{Discussion}

'African Rose ${ }^{\mathrm{TM}}$ '. 'African Rose ${ }^{\mathrm{TM}}$ ' is a self-fertile, early japanese plum (Culdevco, 2009), and therefore sets excessive fruit. In addition, the short fruit development phase tends to result in small fruit size. The highest ACC rate of $500 \mu \mathrm{L} \cdot \mathrm{L}^{-1}$, both alone or in combination with 6-BA, were the only two treatments that had a significant thinning effect in the first season. This was clear from the number of fruitlets that needed to be hand thinned. Exogenously applied Ethephon increases ethylene levels in plants (Wertheim, 1997), thereby stimulating fruit abscission (Wertheim, 2000). A similar response to $\mathrm{ACC}$, a precursor of ethelyne, is expected. 
Table 3. Effect of 6-benzyladenine (6-BA), 1-aminocyclopropane carboxylic acid (ACC), and Darwin $300^{\mathrm{TM}}$ on yield distribution and average fruit weight of 'African Rose ${ }^{\mathrm{TM}}$ ' plum at Sandrivier, Wellington District, South Africa (2014/2015).

\begin{tabular}{lcccc}
\hline & $\begin{array}{c}\text { Percentage of fruit } \\
\text { picked at } \\
\text { first harvest }\end{array}$ & $\begin{array}{c}\text { Percentage of } \\
\text { fruit picked at } \\
\text { second harvest }\end{array}$ & $\begin{array}{c}\text { Percentage of } \\
\text { fruit picked at } \\
\text { third harvest }\end{array}$ & $\begin{array}{c}\text { Avg fruit wt (g) } \\
\text { over three } \\
\text { harvests }\end{array}$ \\
Treatment & $13.5 \mathrm{c}$ & $26.4^{\mathrm{Ns}}$ & $60.1 \mathrm{a}$ & $52.5 \mathrm{c}$ \\
Control & $24.8 \mathrm{bc}$ & 32.7 & $42.6 \mathrm{bc}$ & $59.8 \mathrm{~b}$ \\
Darwin at full bloom & $25.2 \mathrm{bc}$ & 30.7 & $44.1 \mathrm{bc}$ & $57.2 \mathrm{~b}$ \\
Flower thinning & $19.1 \mathrm{bc}$ & 29.1 & $51.8 \mathrm{ab}$ & $52.5 \mathrm{c}$ \\
6-BA $100 \mu \mathrm{L} \cdot \mathrm{L}^{-1}$ & $18.3 \mathrm{bc}$ & 34.8 & $46.9 \mathrm{abc}$ & $59.5 \mathrm{~b}$ \\
ACC 400 $\mu \mathrm{L} \cdot \mathrm{L}^{-1}$ & $15.3 \mathrm{c}$ & 33.7 & $51.0 \mathrm{ab}$ & $66.1 \mathrm{a}$ \\
ACC $600 \mu \mathrm{L} \cdot \mathrm{L}^{-1}$ & $19.8 \mathrm{bc}$ & 42.3 & $37.9 \mathrm{bcd}$ & $64.9 \mathrm{a}$ \\
ACC $800 \mu \mathrm{L} \cdot \mathrm{L}^{-1}$ & $27.6 \mathrm{abc}$ & 37.2 & $35.2 \mathrm{~cd}$ & $59.5 \mathrm{~b}$ \\
6-BA + ACCz & $32.4 \mathrm{ab}$ & 34.8 & $32.8 \mathrm{~cd}$ & $66.2 \mathrm{a}$ \\
Darwin + ACC 600 $\mu \mathrm{L} \cdot \mathrm{L}^{-1}$ & $40.1 \mathrm{a}$ & 33.4 & $26.5 \mathrm{~d}$ & $64.3 \mathrm{a}$ \\
Darwin + ACC $800 \mu \mathrm{L} \cdot \mathrm{L}^{-1}$ & 0.0161 & 0.2523 & 0.0017 & $<0.0001$ \\
Significance level & 14.73 & - & 15.57 & 4.26 \\
Least significant difference 5\% & 0.0006 & 0.3147 & 0.0090 & 0.8858 \\
ACC vs. ACC + Darwin & 0.8399 & 0.1704 & 0.2524 & 0.0134 \\
ACC linear & 0.5568 & 0.3089 & 0.2078 & 0.0391 \\
ACC quadratic & 0.0455 & 0.0556 & 0.0016 & $<0.0001$ \\
Control vs. rest & & & &
\end{tabular}

${ }^{\mathrm{z}} 6-\mathrm{BA}\left(100 \mu \mathrm{L} \cdot \mathrm{L}^{-1}\right)+\mathrm{ACC}\left(800 \mu \mathrm{L} \cdot \mathrm{L}^{-1}\right)$.

Table 4. Effect of 6-benzyladenine (6-BA) and 1-aminocyclopropane carboxylic acid (ACC) on handthinning requirement, fruitlet weight at hand thinning, and average yield per tree of 'Fortune' plum at Sandrivier, Wellington District, South Africa (2014/2015).

\begin{tabular}{lccc}
\hline Treatment & $\begin{array}{c}\text { Avg number of fruitlets } \\
\text { thinned by hand }\end{array}$ & $\begin{array}{c}\text { Avg wt of hand } \\
\text { thinned fruitlets }(\mathrm{g})\end{array}$ & $\begin{array}{c}\text { Total yield } \\
\text { per tree }(\mathrm{kg})\end{array}$ \\
\hline Control & $427 \mathrm{~b}$ & $7.8^{\mathrm{NS}}$ & $12.3 \mathrm{a}$ \\
6-BA $500 \mu \mathrm{L} \cdot \mathrm{L}^{-1}$ & $606 \mathrm{a}$ & 6.8 & $10.9 \mathrm{a}$ \\
ACC $200 \mu \mathrm{L} \cdot \mathrm{L}^{-1}$ & $451 \mathrm{~b}$ & 7.2 & $12.3 \mathrm{a}$ \\
ACC $400 \mu \mathrm{L} \cdot \mathrm{L}^{-1}$ & $239 \mathrm{c}$ & 7.8 & $8.7 \mathrm{~b}$ \\
ACC $600 \mu \mathrm{L} \cdot \mathrm{L}^{-1}$ & $188 \mathrm{c}$ & 7.4 & $8.1 \mathrm{~b}$ \\
6-BA + ACCz & $149 \mathrm{c}$ & 7.9 & $7.8 \mathrm{~b}$ \\
Significance level & $<0.0001$ & 0.1404 & $<0.0001$ \\
Least significant difference 5\% & 123.64 & - & 1.60 \\
Control vs. ACC & 0.0011 & 0.5100 & $<0.0001$ \\
ACC linear & $<0.0001$ & 0.7600 & $<0.0001$ \\
ACC quadratic & 0.1362 & 0.2597 & 0.0345 \\
\hline z6-BA $\left(100 \mu \mathrm{L} \cdot \mathrm{L}^{-1}\right)+\mathrm{ACC}\left(600 \mu \mathrm{L}^{-1}\right)$ & & &
\end{tabular}

${ }^{\mathrm{z}} 6-\mathrm{BA}\left(100 \mu \mathrm{L} \cdot \mathrm{L}^{-1}\right)+\mathrm{ACC}\left(600 \mu \mathrm{L} \cdot \mathrm{L}^{-1}\right)$.

Meland and Birken (2010) found effective thinning of 'Victoria' plums after application of Ethephon at 250,375 , and $500 \mu \mathrm{L} \cdot \mathrm{L}^{-1}$ at full bloom and 125,250 , and $375 \mu \mathrm{L} \cdot \mathrm{L}^{-1}$ at 10-12 mm fruitlet diameter. Schupp et al. (2012) found promising results when ACC was used to thin 'Golden Delicious' apple trees where the thinning effect increased linearly with increasing rate of ACC. In the subsequent season (2014-15), we applied higher rates of ACC (600 and $\left.800 \mu \mathrm{L} \cdot \mathrm{L}^{-1}\right)$, but still a large number of fruit had to be thinned by hand. During both seasons, the most effective ACC treatments showed the benefit of early thinning in that the handthinned fruitlets were already larger at the time of hand thinning. We included the mechanical and hand flower thinning to reduce fruit number earlier and with the settings chosen for the Darwin $300^{\mathrm{TM}}$ it was expected that using the machine at full bloom would have a similar thinning effect as the $50 \%$ hand flower thinning treatment, and both these treatments resulted in larger fruitlets at commercial hand thinning when compared with the control. De Villiers (2014) also evaluated the Darwin $300^{\mathrm{TM}}$ on 'African Rose $^{\mathrm{TM}}$ ' plums with various rotor speeds, viz. 220, 250, and $280 \mathrm{rpm}$ and all treatments season, there was a quadratic effect on the yield with the highest ACC rate of $800 \mu \mathrm{L} \cdot \mathrm{L}^{-1}$ over thinning and resulting in a significantly lower yield than the control. The yield of the $600 \mu \mathrm{L} \cdot \mathrm{L}^{-1}$ ACC-treated trees did not differ significantly from the control, thus indicating this as the recommended ACC rate for 'African Rose ${ }^{\mathrm{TM}}$ '. The yield of the combination treatment of the Darwin $300^{\mathrm{TM}}$ and ACC $600 \mu \mathrm{L} \cdot \mathrm{L}^{-1}$ did not differ from the control even though the thinning effect of the combination treatment was significantly higher than the treatments on their own. The Darwin $300^{\mathrm{TM}}$ on its own and $50 \%$ hand flower thinning during bloom did not significantly reduce yield compared with the control. De Villiers (2014) found similar results for total yield when using the Darwin $300^{\mathrm{TM}}$. With the increase in ACC rates in the 2014/2015 season, a linear decrease in yield was observed as the rate of ACC increased, which should make it possible to find the correct rate of ACC depending on the yield required.

The combination treatments between the Darwin $300^{\mathrm{TM}}$ and ACC did advance harvest and almost $30 \%$ more fruit was picked at the first harvest date. Fruit firmness was not significantly affected (data not shown), indicating that fruit maturity was advanced by the heavy thinning treatments resulting in advanced harvesting, which is a known response to thinning (Costa and Vizzotto, 2000; Wünsche et al., 2000).

In the 2014/2015 season, all the treatments had a significant and positive effect on fruit size except for the 6-BA treatment. Pavel and DeJong (1993) found that individual fruit size increased in trees with lower crop loads compared with the fruit of unthinned trees and this is a well-known response to fruit thinning (Costa et al., 1983; Costa and Vizzotto, 2000). The Darwin $300^{\mathrm{TM}}$ treatment increased the average fruit weight significantly compared with the control, thus corresponding with what De Villiers (2014) found. The two combination treatments of the Darwin $300^{\mathrm{TM}}$ with ACC 600 and $800 \mu \mathrm{L} \cdot \mathrm{L}^{-1}$, and these two ACC rates alone significantly increase fruit size compared with the untreated control, but also more so than the flower thinning treatments alone and the lowest ACC $\left(400 \mu \mathrm{L} \cdot \mathrm{L}^{-1}\right)$ rate. The quadratic effect on fruit size that was observed for the ACC-treated trees indicated that the $600 \mu \mathrm{L} \cdot \mathrm{L}^{-1}$ application had the best effect on fruit size of all the ACC treatments with no further gain above this concentration and again confirming that this should be the recommended rate for 'African Rose ${ }^{\mathrm{TM}}$ '.

'Fortune'. The two higher ACC rates successfully reduced hand fruit thinning as did the combination of ACC and 6-BA. However, in this trial, there was no effect on the average weight of the individual fruitlets thinned by hand. It appears though that these treatments over thinned as the total yield of these treatments was significantly lower compared with the control. It would appear that 'Fortune' is more sensitive to ACC than 'African Rose ${ }^{\mathrm{TM}}$ '. These treatments did not alter the harvest distribution 
Table 5. Effect of 6-benzyladenine (6-BA) and 1-aminocyclopropane carboxylic acid (ACC) on yield distribution and average fruit weight at harvest of 'Fortune' plum at Sandrivier, Wellington District, South Africa (2014/2015).

\begin{tabular}{lccc}
\hline Treatment & $\begin{array}{c}\text { Percentage of fruit } \\
\text { picked at first harvest }\end{array}$ & $\begin{array}{c}\text { Percentage of fruit } \\
\text { picked at second harvest }\end{array}$ & $\begin{array}{c}\text { Avg fruit } \\
\mathrm{wt}(\mathrm{g})\end{array}$ \\
\hline Control & $21.9^{\mathrm{Ns}}$ & $78.1^{\mathrm{Ns}}$ & $88.7 \mathrm{bc}$ \\
6-BA $500 \mu \mathrm{L} \cdot \mathrm{L}^{-1}$ & 18.4 & 81.6 & $85.4 \mathrm{c}$ \\
ACC $200 \mu \mathrm{L} \cdot \mathrm{L}^{-1}$ & 18.3 & 81.7 & $91.9 \mathrm{abc}$ \\
ACC $400 \mu \mathrm{L} \cdot \mathrm{L}^{-1}$ & 31.2 & 68.7 & $95.3 \mathrm{ab}$ \\
ACC $600 \mu \mathrm{L} \cdot \mathrm{L}^{-1}$ & 29.8 & 70.2 & $99.9 \mathrm{a}$ \\
6-BA + ACC & 27.5 & 72.5 & $100.4 \mathrm{a}$ \\
Significance level & 0.0938 & 0.0938 & 0.0064 \\
Least significant difference 5\% & - & - & 8.90 \\
Control vs. ACC & 0.2911 & 0.2911 & 0.0239 \\
ACC linear & 0.0510 & 0.0510 & 0.0780 \\
ACC quadratic & 0.1512 & 0.1512 & 0.8780 \\
\hline 76-BA $\left(100 \mu L^{-1}\right)+\mathrm{ACC}\left(600 \mu \mathrm{L}^{-1}\right)$ & & &
\end{tabular}

${ }^{\mathrm{z}} 6-\mathrm{BA}\left(100 \mu \mathrm{L} \cdot \mathrm{L}^{-1}\right)+\mathrm{ACC}\left(600 \mu \mathrm{L} \cdot \mathrm{L}^{-1}\right)$.

Table 6. Effect of 6-benzyladenine (6-BA) and 1-aminocyclopropane carboxylic acid (ACC) on handthinning requirement, average weight of thinned fruitlets, yield per tree, and average fruit weight at harvest of 'Laetitia' plum at Fransmanskraal, Stellenbosch District, South Africa (2014/2015).

\begin{tabular}{lcccc}
\hline Treatment & $\begin{array}{c}\text { Average number } \\
\text { of fruitlets thinned } \\
\text { by hand }\end{array}$ & $\begin{array}{c}\text { Average weight } \\
\text { of hand thinned } \\
\text { fruitlets }(\mathrm{g})\end{array}$ & $\begin{array}{c}\text { Total yield } \\
\text { per tree }(\mathrm{kg})\end{array}$ & $\begin{array}{c}\text { Average fruit } \\
\text { weight }(\mathrm{g})\end{array}$ \\
\hline Control & $385 \mathrm{a}$ & $4.6 \mathrm{a}$ & $10.7 \mathrm{ab}$ & $73.0 \mathrm{c}$ \\
6-BA $500 \mu \mathrm{L} \cdot \mathrm{L}^{-1}$ & $412 \mathrm{a}$ & $3.9 \mathrm{~b}$ & $11.7 \mathrm{a}$ & $73.2 \mathrm{c}$ \\
ACC $200 \mu \mathrm{L} \cdot \mathrm{L}^{-1}$ & $350 \mathrm{a}$ & $3.9 \mathrm{~b}$ & $10.9 \mathrm{ab}$ & $74.5 \mathrm{c}$ \\
ACC $400 \mu \mathrm{L} \cdot \mathrm{L}^{-1}$ & $217 \mathrm{~b}$ & $3.5 \mathrm{~b}$ & $9.7 \mathrm{bc}$ & $87.4 \mathrm{~b}$ \\
ACC $600 \mu \mathrm{L} \cdot \mathrm{L}^{-1}$ & $171 \mathrm{~b}$ & $3.7 \mathrm{~b}$ & $8.2 \mathrm{c}$ & $91.5 \mathrm{~b}$ \\
6-BA + ACC & $70 \mathrm{c}$ & $3.9 \mathrm{~b}$ & $5.8 \mathrm{~d}$ & $97.6 \mathrm{a}$ \\
Significance level & $<0.0001$ & 0.0561 & $<0.0001$ & $<0.0001$ \\
Least significant difference 5\% & 89.09 & 0.72 & 1.95 & 5.75 \\
Control vs. ACC & $<0.0001$ & 0.0025 & 0.0099 & $<0.0001$ \\
ACC linear & 0.0002 & 0.6548 & 0.0076 & $<0.0001$ \\
ACC quadratic & 0.2661 & 0.3791 & 0.9020 & 0.0824 \\
\hline
\end{tabular}

${ }^{\mathrm{z}} 6-\mathrm{BA}\left(100 \mu \mathrm{L} \cdot \mathrm{L}^{-1}\right)+\mathrm{ACC}\left(600 \mu \mathrm{L} \cdot \mathrm{L}^{-1}\right)$.

in this trial, but did influence fruit size. The average fruit weight of the ACC treated trees was significantly larger than that of the control trees. This is not surprising as it is well known, as stated earlier, that to achieve fruit of adequate size, regulation of crop load is essential (Day and DeJong, 1998). Even though the lower rate of ACC $\left(200 \mu \mathrm{L} \cdot \mathrm{L}^{-1}\right) \mathrm{did}$ not adequately thin the trees, the $400 \mu \mathrm{L} \cdot \mathrm{L}^{-1}$ ACC resulted in over thinning, but on average increased fruit size by regulating the crop load (Day and DeJong, 1998), indicating that somewhere in between 200 and $400 \mu \mathrm{L} \cdot \mathrm{L}^{-1}$ ACC might be the recommended thinning rate for 'Fortune' plums. There was no need for the addition of 6-BA to prevent leaf drop. As a cautionary note, it should be mentioned that this particular orchard did not yield very well during the particular season.

Laetitia. This cultivar does not set as heavily as African Rose ${ }^{\mathrm{TM}}$, therefore, slightly lower rates of ACC were used in a pilot trial in 2013/2014, some promising thinning responses, which led to the full statistical trial the following season. However, the severe leaf drop observed in the pilot trial was important and indicated that applying ACC midday at temperatures exceeding $30{ }^{\circ} \mathrm{C}$ could result in phytotoxicity and applications should be made early morning or during the evening at lower temperatures. During the second season, the two higher ACC rates (400 and $600 \mu \mathrm{L} \cdot \mathrm{L}^{-1}$ ) significantly thinned fruitlets. 6-BA treatment alone did not have any thinning effect when compared with the control, but had an additive thinning effect in combination with the high ACC rate. Because this 'Laetitia' orchard was relatively young and still growing vigorously, the 6-BA could have further stimulated shoot growth (Elfving and Cline, 1993; Green et al., 1992) when added to the ACC causing even more competition between the shoots and fruitlets resulting in more severe thinning. The IAA transport out of all the newly released lateral buds may have correlatively inhibited IAA transport from fruit, thus leading to the abscission of some of them (Bangerth, 2000). Unfortunately, we did not monitor shoot growth in our trials. Another reason for the additive effect could be the surfactants in the 6-BA formulation resulting in more uptake of the ACC, but this response was not observed in 'African Rose ${ }^{\mathrm{TM}}$ ' or 'Fortune'.

The total yield of the trees receiving the $400 \mu \mathrm{L} \cdot \mathrm{L}^{-1}$ ACC application did not differ significantly from the control and would be the recommended rate for 'Laetitia' plums as hand thinning was reduced by $44 \%$ without a negative effect on yield. Even though the highest ACC rate $\left(600 \mu \mathrm{L} \cdot \mathrm{L}^{-1}\right)$ did reduce the number of fruitlets that still needed to be thinned by hand more than the $400 \mu \mathrm{L} \cdot \mathrm{L}^{-1}$ ACC application, the total yield for the high rate was significantly lower compared with the control. The severe thinning effect achieved with the combination treatment
(ACC and 6-BA) did lead to over thinning as indicated by the significantly lower yield than that of the control and the highest ACC rate application. The two higher ACC concentrations ( 400 and $600 \mu \mathrm{L} \cdot \mathrm{L}^{-1}$ ) had a positive effect on fruit weight. The largest fruit obtained with $600 \mu \mathrm{L} \cdot \mathrm{L}^{-1}$ might not have compensated for the lower yield, and it is important to find the balance between yield and average fruit size (Njoroge and Reighard, 2008).

\section{Conclusion}

We obtained promising fruitlet thinning with ACC on japanese plums. The data indicated that for a self-fertile cultivar like African Rose ${ }^{\mathrm{TM}}$, a higher rate of $600 \mu \mathrm{L} \cdot \mathrm{L}^{-1}$ should be used and possibly also combined with mechanical flower thinning. 'Laetitia' could be thinned effectively by using a lower rate of $400 \mu \mathrm{L} \cdot \mathrm{L}^{-1}$, whereas in the case of 'Fortune', even a lower rate could be enough. Although positive results regarding yield and fruit size were obtained for both 'African Rose $^{\mathrm{TM}}$ ' and 'Laetitia', there is some concern regarding the yield in the 'Fortune' trial. Therefore, the recommended use of ACC might be cultivar specific and further trials are needed before final recommendations can be made. In addition, it could be interesting to evaluate earlier application, i.e., at fruitlet diameter of 4-6 mm, especially in 'African Rose $^{\mathrm{TM}}$ ' that has a very short fruit growth period. The Darwin $300^{\mathrm{TM}}$ shows promise. The hand thinning required following the Darwin $300^{\mathrm{TM}}$ was $\approx 50 \%$ less than that of the untreated control, without negatively influencing yield and with a positive effect on fruit size. No leaf drop/phytotoxicity was observed when ACC was applied during cool conditions, but high temperatures should be avoided.

\section{Literature Cited}

Adams, D.O. and S.F. Yang. 1979. Ethylene biosynthesis: Identification of 1-aminocyclopropane1-carboxylic acid as an intermediate in the conversion of methionine to ethylene. Proc. Natl. Acad. of Sci. of Amer. 76(1):170-174.

Baugher, T.A., J.R. Schupp, K.M. Lesser, and K. Hess-Reichard. 2009. Horizontal string blossom thinner reduces labor input and increases fruit size in peach trees trained to opencenter systems. HortTechnology 19:755-761.

Baugher, T.A., K. Ellis, J. Remcheck, K. Lesser, J. Schupp, E. Winzeler, and K. Reichard. 2010. Mechanical string thinner reduces crop load at variable stages of bloom development of peach and nectarine trees. HortScience 45:1327-1331.

Bangerth, F. 2000. Abscission and thinning of young fruit and their regulation by plant hormones and bioregulators. Plant Growth Regulat. 31(1):43-59.

Byers, R.E. and D.H. Carbaugh. 1991. Effect of chemical thinning sprays on apple fruit set. HortTechnology 1:41-48.

Byers, R.E., D.H. Carbaugh, and C.N. Presley. 1990. Influence of bloom thinning and GA3 sprays on flower bud numbers and distribution in peach trees. J. Hort. Sci. 65(2):143-150.

Costa, G., C. Giulivo, and A. Ramina. 1983 Effects of the different flower/vegetative buds 
ratio on the peach fruit abscission and growth. Acta Hort. 139:149-160.

Costa, G. and G. Vizzotto. 2000. Fruit thinning of peach trees. Plant Growth Regulat. 31:113119.

Culdevco. 2009. <http://www.culdevco.co.za/ images/stories/STONE/AFRICANROSEARCPR4-Releasedin2009.pdf>.

Day, K.R. and T.M. DeJong. 1998. Improving fruit size: Thinning and girdling nectarines, peaches, and plums. The Compact Fruit. Tree 32(2):1-6.

DeJong, T. and Y.L. Grossman. 1994. A supply and demand approach to modeling annual reproductive and vegetative growth of deciduous fruit trees. HortScience 29:1435-1442.

De Villiers, M.H.J. 2014. Mechanical and chemical thinning of stone fruit. MSc Agr thesis, Stellenbosch University, South Africa.

Elfving, D.C. and R.A. Cline. 1993. Benzyladenine and other chemicals for thinning Empire apple trees. J. Amer. Soc. Hort. Sci. 118:593-598.

Fallahi, E., B. Fallahi, J.R. McFerson, R.E. Beyers, R.C. Ebel, R.T. Boozer, J. Pitts, and B.S. Wilkins. 2006. Tergitol-TMN-6 surfactant is an effective blossom thinner for stone fruits. HortScience 41:1243-1248.

González-Rossia, D., M. Juan, C. Reig, and M. Agusti. 2006. The inhibition of flowering by means of gibberellic acid application reduces the cost of hand thinning in Japanese plums (Prunus salicina Lindl.). Sci. Hort. 110 (4):319-323.

Green, D.W., W.R. Autio, J.A. Erf, and Z.Y. Mao. 1992. Mode of action of benzyladenine when used as a chemical thinner on apples. J. Amer. Soc. Hort. Sci. 117:775-779.

Grossman, Y.L. and T. DeJong. 1995. Maximum fruit growth potential and seasonal patterns of resource dynamics during peach growth. Ann. Bot. 75:553-560.

Martín, B., A. Torregrosa, and J. Garcia Brunton. 2010. Post-bloom thinning of peaches for canning with hand-held mechanical devices. Sci. Hort. 125(4):658-665.

Meland, M. 2007. Efficacy of chemical bloom thinning agents to European plums. Acta Agr. Scand. B-S P 57(3):235-242.

Meland, M. and E. Birken. 2010. Ethephon as a blossom and fruitlet thinner affects crop load, fruit weight and fruit quality of the European plum cultivar 'Jubileum'. Acta Hort. 884:315322.

Miller, S.S., J.R. Schupp, T.A. Baugher, and S.D. Wolford. 2011. Performance of mechanical thinners for bloom or green fruit thinning in peaches. HortScience 46:43-51.

Njoroge, S.M.C. and G.L. Reighard. 2008. Thinning time during stage I and fruit spacing influences fruit size of 'Contender' peach. Sci. Hort. 115(4):352-359.

Pavel, E. and T. DeJong. 1993. Source-and sinklimited growth periods of developing peach fruits indicated by relative growth rate analysis. J. Amer. Soc. Hort. Sci. 118:820-824.

Reighard, G. and R. Byers. 2009. Peach thinning. Department of Horticulture, Clemson University. Clemson, SC, retrieved 22 Nov.

Schupp, J.R., T.M. Kon, and H.E. Winzeler. 2012. 1 -aminocyclopropane carboxylic acid shows promise as a chemical thinner for apple. HortScience 47:1308-1311.

Schupp, J.R., T.A. Baugher, S.S. Miller, R.M Harsh, and K.M. Lesser. 2008. Mechanical thinning of peach and apple trees reduces labor input and increases fruit size. HortTechnology $18: 660-670$
Seehuber, C., L. Damerow, and M. Blanke. 2011. Regulation of source: Sink relationship, fruit set, fruit growth and fruit quality in European plum (Prunus domestica L.) - Using thinning for crop management. Plant Growth Regulat. 65(2):335-341.

Southwick, S.M., K.G. Weis, and J.T. Yeager. 1996. Bloom thinning 'Loadel' cling peach with a surfactant. J. Amer. Soc. Hort. Sci. 121:334-338.

Theron, K.I., M.H.J. De Villiers, and W.J. Steyn. 2015. Is mechanical blossom thinning a viable alternative to hand thinning for stone fruit? S.A. Fruit J. (June/July):72-73.

Wertheim, S.J. 1997. Chemical thinning of deciduous fruit trees. Acta Hort. 463:445-462.

Wertheim, S.J. 2000. Developments in the chemical thinning of apple and pear. Plant Growth Regulat. 31:85-100.

Wilkins, B.S., R.C. Ebel, W.A. Dozier, J. Pitts, and R. Boozer. 2004. Tergitol TMN-6 for thinning peach blossoms. HortScience 39:16111613.

Wünsche, J.N., J.W. Palmer, and D.H. Greer. 2000. Effects of crop load on fruiting and gasexchange characteristics of 'Braeburn'/M.26 apple trees at full canopy. J. Amer. Soc. Hort. Sci. 125:93-99.

Yoshii, H. and H. Imaseki. 1981. Biosynthesis of auxin-induced ethylene. Effects of indole-3acetic acid, benzyladenine and abscisic acid on endogenous levels of 1-aminocyclopropane-1carboxylic acid (ACC) and ACC synthase. Plant Cell Physiol. 22(3):369-379.

Zieslin, N. and V. Gottesman. 1983. Involvement of ethylene in the abscission of flowers and petals of Leptospermum scoparium. Physiol. Plant. 58(1):114-118. 